\title{
Ebeveynlere Bağlanma ile Kişilik Özellikleri Arasındaki İlişki
}

\author{
Yıldız Öztan ULUSOY ${ }^{1 *}$, Osman Nejat AKFIRAT ${ }^{1}$, Gülşah TURA ${ }^{1}$
}

Öz

Anne ve babayla kurulan duygusal bağlar ve onlardan alınan destek, bireylerin kimlik gelişiminde önemli bir etkiye sahiptir. Bireyin gelişiminde ayrışma ve bireyleşme önemli bir yer tutmaktadır. Üniversiteli gençlerin birey olma sürecinde, ayrışma ve bireyleşme sürecinde deneyimlerden geçmeleri nedeniyle bu dönem önemlidir..Bu çalışma ile Marmara bölgesinde bulunan bir üniversitenin 2017- 2018 öğretim yılında Eğitim Fakültesinin farklı bölümlerine kayıt yaptıran birinci sınıf öğrencilerinin bağlanma ve kişilik özellikleri arasındaki ilişkinin incelenmesi amaçlanmıştır. Bu çalışma, betimsel ilişkisel tarama modelinde bir araştırmadır. Beş Faktör Kişilik Ölçeği ve Ebeveyn ve Arkadaşlara Bağlanma Envanteri (EABE) Kısa Formu ölçeği kullanılmıştır. Katılımcılar, 196 kadın ve 69 erkek olmak üzere toplam 267 kişidir. Örneklemi oluşturan öğrencilerin yaş ortalaması 18 dir. Çalışmanın sonucunda, katılımcıların anne ve baba bağlanma özellikleri ile dışa dönüklük, yumuşak başılıı ve uzlaşabilirlik özelliği arasında anlamlı ilişki bulunmuştur. Nevrotiklik ile baba bağlanma puanları arasında olumsuz yönde düşük anlamlı ilişki saptanmıştır. Anne/babaya güvenli bağlanma düzeylerinde cinsiyetin, anne öğreniminin ve kardeş sayısının etkili olduğu görülmüştür.

Anahtar kelimeler: Bağlanma, kişilik özellikleri, ebeveyne bağlanma

\section{The Relationship Between Parental Attachment And Personality Traits}

\begin{abstract}
The emotional ties with the parents and the support received from them have an important influence on the personality development of the individual (Disintegration and individualization play an important role in the development of the individual. University has an important place in the process of being an individual for the young people. The young people who leave their family for the first time have different experiences in the process of separation and individuation. The aim of this study is to examine the relationship between attachment and personality traits of first year students who enrolled in different departments of the Faculty of Education at KOU University in the 2017-2018 academic year. In this study, the relational screening model which is a descriptive research method was employed. The Big Five Factor inventory and the scale of psychometric assessment of the Inventory of Parents and Peer Attachment-Short Form were used. Participants are a total of 267 people, 196 females and 69 males. The average age of the participants is 18. As a result of the study, there was a significant relationship between the participants' parental attachment characteristics and the personality traits such as extroversion, tender mindedness and consociationalism. There was a low negative correlation between neuroticism and father
\end{abstract}

\footnotetext{
${ }^{1}$ Dr. Öğr.Üyesi, Eğitim Bilimleri Bölümü, Kocaeli Üniversitesi, Kocaeli

*ilgili yazar / Corresponding author: yildizoz10@hotmail.com

Gönderim Tarihi: 25.06.2018

Kabul Tarihi: 27.06.2018
}

Bu makaleye atıf yapmak için- To cite this article Öztan Ulusoy, Y., Akfırat, O., \& Tura, G. (2018). Ebeveynlere Bağlanma ile Kişilik Özellikleri Arasındaki İlişki. Resilience, 23-38. 
attachment scores. Gender, mother's education level and number of siblings were found to be effective on the young people's secure attachment to their parents. Support programs about extroversion, self-discipline and consociationalism can be organized for the students with a low level of attachment. In this regard, in the further studies, research about developing self-discipline and appropriate coping strategies for those with low father attachment can be done.

Keywords: Attachment, Personality Traits, Parental Attachment

\section{GíRiş}

Bağlanma, doğumuyla birlikte olgunlaşmasını tamamlamamış olan bireylerin yaşamla daha rahat baş edebilmek için ilgi ve bakım intiyaçlarını karşılayan kişilere, genellikle ebeveynlere karşı geliştirdiği güçlü duygusal bağ olarak tanımlanmaktadır (Bowlby, 1979; 1988). Bireyin erken yaşlarda bakım veren kişiyle kurduğu olumlu etkileşimle birlikte gelişen değerli olma duygusu, kendine ve diğerlerine dair olumlu beklentiler geliştirmesini desteklemekte ve güvenli bağlanmanın oluşumu için önemli bir yapıtaşı olmaktadır. Buna karşın bireylerin bakım veren kişiyle kurdukları ilişki sonrasında gelişen değersizlik duyguları, onların kendilerine ve diğerlerine ilişkin olumsuz beklentiler geliştirmesine yol açmakta, dolayısıyla güvensiz bağlanmanın (kaygılı-kararsız veya kaçınmalı) oluşmasına zemin hazırlamaktadır (Bowlby, 1979).

Bağlanmayı kişilik gelişimi olarak ele alan Bowlby (1958), insan bağlanmasını doğumda başlayan ve erişkin dönemde de süreklilik gösteren, yaşam boyu devam eden ve gelişen bir süreç olarak ele almıştır. Dolayısıyla çocuklukta kurulan bağlanma ilişkisi bireylerin, ergenlik ve yetişkinlik dönemlerinde diğer insanlarla kuracakları ilişkilerde belirleyici bir faktör olmaktadır (Ainsworth, 1989; Bowbly, 1988; Fraley ve Shaver, 2000; Mikulincer ve Shaver, 2007). Anne ve babayla kurulan duygusal bağlar ve onlardan alınan destek, bireylerin kimlik gelişiminde önemli bir etkiye sahiptir (Allen, Hauser, Bell, Eickolt ve O'Conner, 1994). Akran etkisinin öne çıkması ile bireylerinebeveynlerine olan bağlıı̆ının giderek azaldığı ergenlik ve geç ergenlik dönemleri, sağlıklı kişilik gelişiminin gerçekleşmesi açıcından anne ve babayla kurulan duygusal bağların ve intiyaç halinde onlardan alınabilecek desteğin hala önemli olduğu bir evre olarak değerlendirilmektedir (Hazan ve Zeifman, 1994).

Kişilik, bireyin kendine has, tutarlı, tahmin edilebilir özelliklerini kapsayan ve kendisi ve dış dünya ile olan ilişkisinin niteliğini belirleyen özellikler bütünü olarak tanımlanabilir. Beş Faktör (Big Five) Kişilik Modeli'ni geliştiren McCrae ve Costa (1989)'ya göre kişilik, sürekliliği olan, bireyin farklı durumlarda ortaya koyduğu kişilerarası duygusal, motivasyonel ve deneyime dayalı etkileşim tarzıdır. Beş faktör kişilik modeli dışa dönüklük, deneyime açıklık, sorumluluk, nevrotiklik ve yumuşak başlılık faktörlerinden oluşmaktadır. (Costa ve McCrae, 1989; 1992; 2003). Bu modelde dışa dönüklük; konuşkan, sosyal, iyimser, sevecen olarak; deneyime açıklık; ilgili, meraklı, yaratıcı, değişime açık olarak; sorumluluk; çalışkan, güvenilir, azimli, dakik, planlı, düzenli olarak; yumuşak başılık; yardımsever, hoşgörülü, bağışlayıcı, doğru sözlü, merhametli olarak ve nevrotiklik ise endişeli, sinirli, depresif, gergin ve kaygılı kişiler olarak tanımlanmaktadır.

Kişilik özellikleri ile bağlanma arasındaki ilişkilerin incelendiği araştırmalarda nevrotik kişilik özelliğine sahip bireylerin korku ve saplantılı bağlanma stiline daha yatkın olduğu (Carver, 1997; Shaver ve Brennan; 1992), dışa dönük kişilik özelliğine sahip bireylerin ise güvenli bağlanma stili puanlarının yüksek olduğu (Carver, 1997; Wilkinson ve Walford, 2001) ortaya konulmuştur. 
Kimlik gelişiminde ve gelişen kimliğin korunmasında aile yaşamı, çevre, sosyal statü gibi pek çok faktör etkilidir (Steinberg,2005).

Yakınlaşma becerileri bireylerin, akranları, aile üyeleri, komşuları, okul arkadaşları ve çalışma arkadaşları ile ilişkiler geliştirmesini ve sürdürmesini sağlayan iletişim becerileridir. Bunlar arkadaşlığın, sevginin, birlikte yaşamının ve aile ilişkilerinin temelidir. Yakınlaşma becerileri toplumsal destek, sevgi, dostluk ve ilişkilerde karşılılık kazanmak için esastır. Kişisel kimliğimiz büyük oranda aile ve grup üyeliği ile belirlendiğinden, yakınlaşma becerileri iyileşme ve anlamlı bir yaşam için büyük önem taşımaktadır (Liberman, 2011). Güvenli bağlanma geliştirmiş kişiler ilişkilerinde mutlu ve güvenli kişilerdir.

Bireyin gelişiminde ayrışma ve bireyleşme önemli bir yer tutmaktadır. Türk kültürü toplulukçu bir kültür olduğu için ayrışma ve bireyleşme konusunda gençlere sunulan fırsatlar sınırlı olabilmektedir. Üniversite gençlerin birey olma sürecinde önemli bir yere sahiptir. Ailesinden ilk kez ayrılan gençler ayrışma ve bireyleşme sürecinde deneyimlerden geçmektedir. Anneye ve babaya bağlanma ve kişisel uyum arasındaki ilişkide ayrışma bireyleşmenin aracılığı kabul edilmiştir. Anneye ve babaya güvenli bağlanma ve kişisel uyum arasındaki ilişkide ayrışma bireyleşmenin aracılığının Türk kültüründe geçerli olduğu görülmüştür (Aslan ve Güven, 2010). Bireyleşme sürecinde gencin, kişilik özellikleri ve bağlanma özellikleri arasındaki ilişkinin ele alınmasının önemli olduğu düşünülmektedir.

Bu çalışma ile Marmara bölgesinde bulunan bir üniversitenin 2017- 2018 öğretim yılında Eğitim Fakültesinin farklı bölümlerine kayıt yaptıran birinci sınıf öğrencilerinin bağlanma ve kişilik özellikleri arasındaki ilişkinin incelenmesi amaçlanmıştır. Bu amaçla aşağıda belirtilen sorulara cevap aranmıştır.

1- Öğrencilerin kişilik özellikleri puanları ile ebeveyn bağlanma puanları arasında anlamlı bir ilişki var mıdır?

2- Öğrencilerin ebeveyn bağlanma düzeyleri ve kişilik özellikleri cinsiyetlerine göre anlamlı bir farklılık göstermekte midir?

3- Öğrencilerin ebeveyn bağlanma düzeyleri ve kişilik özellikleri anne/ baba öğrenim düzeylerine göre anlamlı bir farklılık göstermekte midir?

4- Öğrencilerin ebeveyn bağlanma düzeyleri ve kişilk özellikleri kardeş sayısına göre anlamlı bir farklılık göstermekte midir?

\subsection{Yöntem}

Bu çalışma, betimsel ilişkisel tarama modelinde bir araştırmadır. Betimsel tarama modeli olayların, varlıkların, grupların, mevcut durum ve özelliklerini kendi koşullarında betimlemeye ve incelemeye çalışan bir araştırma modelidir (Kaptan, 1998: 53).Tarama modelindeki araştırmalar, görüşlerin ve özelliklerin örneklemdeki bireyler açısından nasıl dağıldığı hakkında bilgi, neden kaynaklandığı hakkında ise ipucu verir (Creswell, 2005; Fraenkel ve Wallen, 2003). Tarama modelinde amaç; bir topluluğa ait olan bir grup bireyin herhangi bir konuya ilişkin görüşleri, tutumları, inançları veya bilgilerini betimlemektir (Fraenkel ve Wallen, 2003). Tarama modelleri, geçmişte ya da halen var olan bir durumu var olduğu şekliyle betimlemeyi amaçlayan araştırmalara uygun bir modeldir (Karasar 2005: 183). Iliş̧kisel tarama modelleri ise; iki ve daha fazla değişken arasındaki birlikte değişim varlığını belirlemeyi amaçlayan araştırma modelleri için kullanıldığından bu araştırma için uygun görülmektedir. 


\subsection{Araştırma Grubu}

Araştırmanın evrenini 2017- 2018 öğretim yılında Marmara bölgesinde bulunan bir üniversitenin Eğitim Fakültesi'nde öğrenim gören; İngilizce, Matematik, Türkçe, Sınıf, Fen Bilgisi, Okul Öncesi Öğretmenliği ve Psikolojik Danışma ve Rehberlik lisans programı birinci sınıf öğrencileri oluşturmaktadır. Katılımcılar 196 kadın ve 69 erkek olmak üzere toplam 267 kişidir. Örneklemi oluşturan öğrencilerin yaş ortalaması 18 dir.

Araştırma grubuna ilişkin toplanan demografik verilere göre grubun \%40,8 i iki, \%55,5 i üç ve daha fazla kardeştir. Tek çocuk olanlar grubun \%5.2'sini oluşturtmaktadır. Katılımcıların $\% 48,3$ 'ü birinci, \%30,3'ü ikinci, \%11,2'si üçüncü çocuktur. Katılımcıların \%32,2 si ailesi ile birlikte, $\% 58,8 \mathrm{i}$ ise yurtta kalmaktadır.

Anne öğrenim düzeyleri açısından katılımcıların \%44,9 u ilkokul mezunu, ortaokul ve lise mezunlarının toplamı \%39,7 dir. Baba öğrenim düzeyleri açısından katılımcıların, \%29,2 si ilkokul mezunu, ortaokul ve lise mezunlarının toplamı \%45,3, üniversite ve üstü öğrenim gören babalar ise $\% 22,5$ dir. Katılımcıların $\% 87,3$ ü orta gelir düzeyindedir.

\subsection{Veri Toplama Araçları}

\section{Beş Faktör Kişilik Ölçeği}

Beş Faktör Kişilik Ölçeği (BFKÖ), kişilik özelliklerini ölçebilmek amacıyla Benet-Martinez ve John (1998) tarafından geliştirilmiştir. BFKÖ, özbildirim tarzı, 5'li Likert tipi 44 maddelik bir ölçme aracıdır. Ölçek, dışa dönüklük, duygusal dengesizlik (nevrotiklik), yumuşak başlılık, sorumluluk ve deneyime açıklık olmak üzere beş faktörden oluşmaktadır. Ölçeğin Türkçe'ye uyarlaması 56 ülkeye ait katılımcıların kişilik özellikleri konusunda yapılan bir çalışmanın (Schmitt, Allık, McCrae ve ark., 2007) Türkiye ayağı kapsamında, Sümer ve Sümer (2005) tarafından yapılmıştır. Bu çalışma için yapılan güvenirlik analizinde de 0.64 ile .85 arasnda güvenirlik katsayılarına ulaşıımıştır.

\section{Ebeveyn ve Arkadaşlara Bağlanma Envanteri Kısa Formu (EABE-KF)}

Çalışmada, Raja ve arkadaşları (1992) tarafından geliştirilen Ebeveyn ve Arkadaşlara Bağlanma Envanteri -Kısa Formu (EABE-KF) kullanılmıştır. Türkçeye adaptasyonu,(Günaydın, Selçuk, Sümer, \& Uysal, 2005) tarafından yapılan Ebeveyn ve Arkadaşlara Bağlanma Envanteri (EABE) 12 maddeden oluşmakta ve ebeveyn ve akrana bağlanmayı ölçen iki alt ölçekten oluşmaktadır. EABE, 7 basamaklı ölçekler üzerinden değerlendirimiştir ( 1 = asla, 7 = daima) ve katılımcılar tarafından hem anne hem de baba için cevaplandırılmıştır. Böylelikle, Güven, iletişim ve ters kodlanan Yabancılaşma alt ölçeklerinin toplanmasıyla toplam bağlanma puanı, anne ve baba için ayrı ayrı hesaplanabilmektedir. Çalışmada anne /baba bağlanma toplam puanları kullanılmmıştır. Ölçeğin ebeveyn formunun geçerlik güvenirlik analizleri üniversite (Günaydın ve ark., 2005) ve lise (Bayraktar, Sayıl, \& Kumru, 2009) örneklemleri üzerinde yapılmıştır ve iç tutarlık katsayısının lise örneklemi için $\alpha=.84$ olduğu bulunmuştur. . Bu çalışma için yapılan güvenirlik analizinde ise güvenirlik katsayısı 0.89 olarak bulunmuştur 


\subsection{Bulgular}

1- Öğrencilerin kişilik özellikleri puanları ile ebeveyn bağlanma puanları arasında anlamlı bir ilişki var mıdır?

Tablo -1 EABE-KF ve Beş Faktör Kişilik Ölçeği'ne İlişkin Betimsel İstatistikler ve Korelasyonlar

\begin{tabular}{lcccccccc}
\hline & $\mathrm{n}$ & 1 & 2 & 3 & 4 & 5 & 6 & 7 \\
\hline 1 ANNEBAĞLANMA & 259 & & & & & & & \\
2 BABABAĞLANMA & 259 &, $532^{* *}$ & & & & & & \\
3 DIŞADÖNÜKLÜK & 259 &, $276^{* *}$ &, $167^{* *}$ & & & & & \\
4 UZLAŞILABILIRLIK & 259 &, $241^{* *}$ &, $257^{* *}$ &, 108 & & & & \\
5 ÖZDISIPLIN & 259 &, $306^{* *}$ &, $329^{* *}$ &, $188^{* *}$ &, $255^{* *}$ & & & \\
6 NEVROTIKLIK & 259 &,- 102 &,$- 140^{*}$ &,$- 344^{* *}$ &, 007 &,$- 155^{*}$ & & \\
7 DENEYIME & 259 &,- 062 &,- 037 &, $263^{* *}$ &, 006 &, 048 &,- 087 & \\
AÇIKLIK & 259 & 68,27 & 62,86 & 25,73 & 33,91 & 32,16 & 25,07 & 35,24 \\
\multicolumn{1}{c}{$\bar{x}$} & 259 & 10,79 & 14,78 & 5,85 & 5,59 & 5,76 & 5,95 & 6,11 \\
\hline \multicolumn{1}{c}{ SS } & & & & & & & & \\
\hline
\end{tabular}

Tablo 1'de görüldüğü gibi araştırma grubundaki öğrencilerin EABE-KF'nin anneye bağlanma puanına ilişkin $\bar{x}=68.17$, babaya bağlanma için $\bar{x}=62.86$ 'dır. Anne ve babaya bağlanma ölçeklerinden alınabilecek en yüksek puan 84 'tür. Bu ölçeklerden ortalamanın üstünde puan almak bireyin anne ve babaya güvenli bağlandığını göstermektedir. Dolayısıyla bu araştırma grubundaki öğrencilerin anne ve babalarına güvenli bağlandıkları ve anneye bağlanma puan ortalamalarının babaya bağlanma puan ortalamalarından yüksek olduğu söylenebilir.

Anne bağlanma puanları ile; dışadönüklük $(p=.276<0.01)$, uzlaşılabilirlik $(p=.241<0.01)$ ve özdisiplin $(p=.306<0.01)$ puanları arasında orta düzeyde, baba bağlanma puanlarıyla; dışadönüklük $(p=.167<0.01)$, uzlaşılabilirlik $(p=.257<0.01)$, özdisiplin $(p=.329<0.01)$ puanları arasında orta düzeyde ve nevrotiklik

$(p=-.140<0.05)$ puanları arasında düşük ve negatif düzeyde ilişki bulunmuştur.

2- Öğrencilerin ebeveyn bağlanma düzeyleri ve kişilik özellikleri cinsiyetlerine göre anlamlı bir farklılık göstermekte midir?

Öğrencilerin anne ve baba bağlanma düzeylerinin ve kişilik özelliklerinin cinsiyete göre farklılaşıpfarklılaşmadığına bakılmıştır. 
Ebeveynlere Bağlanma ile Kişilik Özellikleri Arasındaki Illişki

The Relationship Between Parental Attachment And Personality Traits

Tablo-2 Öğrencilerin Cinsiyetlerine Göre Kişilik özellikleri ve Bağlanma puanlarına İlişkin Ortalama ve MannWhitney U Testi Sonuçları

\begin{tabular}{|c|c|c|c|c|c|c|}
\hline Boyutlar & Cinsiyet & $\bar{x}$ & $\begin{array}{c}\text { Sıra } \\
\text { Ortalaması }\end{array}$ & Sıra Toplamı & $U$ & $P^{*}$ \\
\hline Anne & $\mathrm{K}$ & 64.5907 & 137.49 & 26536.50 & 5501.500 & $.032^{*}$ \\
\hline Bağlanma & $E$ & 62.6087 & 114.73 & 7916.50 & & \\
\hline Baba & $\mathrm{K}$ & 59.1710 & 122.68 & 25988.00 & 6050.00 & .260 \\
\hline Bağlanma & $E$ & 57.7391 & 134.65 & 8465.00 & & \\
\hline \multirow{2}{*}{ Dışa dönüklük } & $\mathrm{K}$ & 25.4974 & 129.75 & 25042.00 & 6321.000 & .532 \\
\hline & $E$ & 26.2174 & 136.39 & 9411.00 & & \\
\hline \multirow{2}{*}{ Uzlaşılabilirlik } & $\mathrm{K}$ & 34.0725 & 136.36 & 26317.50 & 5720.500 & .082 \\
\hline & $E$ & 33.4203 & 117.91 & 8135.50 & & \\
\hline \multirow{2}{*}{ Özdisiplin } & $\mathrm{K}$ & 32.5803 & 136.99 & 26438.50 & 5599.500 & $.050^{\star}$ \\
\hline & $E$ & 30.8696 & 116.15 & 8014.50 & & \\
\hline \multirow{2}{*}{ Nevrotiklik } & $\mathrm{K}$ & 26.1036 & 144.19 & 27829.50 & 4208.500 & $.000 *$ \\
\hline & $E$ & 22.2174 & 95.99 & 6623.50 & & \\
\hline Deneyime & $\mathrm{K}$ & 34.8653 & 126.62 & 24438.00 & 5717.000 & .081 \\
\hline açıklık & $E$ & 36.2029 & 145.14 & 10015.00 & & \\
\hline
\end{tabular}

$P^{*}<.05 N_{K}=193 N_{E}=69 N_{T}=262$

Tablo 2'de görüldüğü gibi öğrencilerin cinsiyetlerine göre anne bağlanma $(U=5501.5, p<.05)$, özdisiplin $(U=5599.5, p<.05)$ ve nevrotiklik $(U=4208.5, p<.05)$ puanlarına ilişkin yapılan Mann-Whitney $U$ testi sonucunda anlamlı bir fark saptanmıştır. Puanların ortalamaları incelendiğinde, kadınların ( $\bar{x}=64.597)$,erkeklere $(\bar{x}=62.6087)$ göre anne bağlanma puanlarının daha yüksek olduğu, kadınların ( $\bar{x}=32.5803)$, erkeklere $(\bar{x}=30.8696)$ göre özdisiplin puanlarının daha fazla ve kadınların $(\bar{x}=26.1036)$, erkeklere $(\bar{x}=22.2174)$ göre nevrotiklik puanlarının daha fazla olduğu saptanmıştır.

3- Öğrencilerin ebeveyn bağlanma düzeyleri ve kişilik özellikleri anne/ baba öğrenim düzeylerine göre anlamlı bir farklılık göstermekte midir?

Tablo-3 Öğrencilerin Anne Öğrenim Düzeylerine Göre Kişilik özellikleri ve Bağlanma puanlarına İlişkin Ortalama ve Kruskall-Wallis Analizi Sonuçları

\begin{tabular}{|c|c|c|c|c|c|c|}
\hline Boyutlar & Anne öğrenim & $\bar{x}$ & $\begin{array}{c}\text { Sıra } \\
\text { Ortalaması }\end{array}$ & $x^{2}$ & $P^{*}$ & $\begin{array}{l}\text { Fark (Mann- } \\
\text { Whitney U) }\end{array}$ \\
\hline \multirow{4}{*}{$\begin{array}{c}\text { Anne } \\
\text { Bağlanma }\end{array}$} & Ílkokul & 64.5887 & 135.28 & \multirow{4}{*}{4.448} & \multirow{4}{*}{.217} & \multirow[t]{4}{*}{ 等, } \\
\hline & Ortaokul & 62.3333 & 112.43 & & & \\
\hline & Lise & 64.6400 & 139.79 & & & \\
\hline & Üniversite & 63.5882 & 136.38 & & & \\
\hline \multirow{4}{*}{$\begin{array}{c}\text { Baba } \\
\text { Bağlanma }\end{array}$} & İlkokul & 61.2057 & 143.49 & \multirow{4}{*}{14.913} & \multirow{4}{*}{$.002^{*}$} & \multirow{4}{*}{$1>2,4$} \\
\hline & Ortaokul & 54.2222 & 108.81 & & & \\
\hline & Lise & 60.5200 & 137.75 & & & \\
\hline & Üniversite & 48.2353 & 85.79 & & & \\
\hline \multirow{4}{*}{ Dışa dönüklük } & Ílkokul & 25.9291 & 134.76 & \multirow{4}{*}{3.200} & \multirow{4}{*}{.362} & \multirow{4}{*}{-} \\
\hline & Ortaokul & 24.6481 & 115.60 & & & \\
\hline & Lise & 25.9400 & 135.45 & & & \\
\hline & Üniversite & 26.2353 & 143.38 & & & \\
\hline \multirow{4}{*}{ Uzlaşılabilirlik } & İlkokul & 34.5390 & 142.40 & \multirow{4}{*}{10.651} & \multirow{4}{*}{$.014^{*}$} & \multirow{4}{*}{$1>4$} \\
\hline & Ortaokul & 33.2778 & 113.28 & & & \\
\hline & Lise & 33.8000 & 133.71 & & & \\
\hline & Üniversite & 30.8824 & 92.44 & & & \\
\hline \multirow{4}{*}{ Özdisiplin } & Ílkokul & 32.5887 & 137.93 & \multirow{4}{*}{3.512} & \multirow{4}{*}{.319} & \multirow{4}{*}{-} \\
\hline & Ortaokul & 31.8889 & 127.93 & & & \\
\hline & Lise & 31.8800 & 126.35 & & & \\
\hline & Üniversite & 29.8235 & 104.65 & & & \\
\hline \multirow{4}{*}{ Nevrotiklik } & İlkokul & 24.7943 & 127.48 & \multirow{4}{*}{3.468} & \multirow{4}{*}{.325} & \multirow{4}{*}{-} \\
\hline & Ortaokul & 24.5000 & 127.33 & & & \\
\hline & Lise & 25.7600 & 137.23 & & & \\
\hline & Üniversite & 27.2941 & 161.21 & & & \\
\hline \multirow{4}{*}{$\begin{array}{l}\text { Deneyime } \\
\text { açıklık }\end{array}$} & İlkokul & 34.8156 & 125.96 & \multirow{4}{*}{6.974} & \multirow{4}{*}{.073} & \multirow{4}{*}{-} \\
\hline & Ortaokul & 34.3519 & 121.65 & & & \\
\hline & Lise & 36.2400 & 146.25 & & & \\
\hline & Üniversite & 38.2941 & 165.35 & & & \\
\hline
\end{tabular}

Sd (3) $P^{*}<.05 N_{\text {likokul }}=141 N_{\text {ortaokul }}=54 N_{\text {Lise }}=50 N_{\text {Universite }}=17 N_{T}=262$ 
Tablo 3'de görüldüğü gibi öğrencilerinin anne öğrenim düzeylerine göre Kruskall-Wallis analizi sonucunda .05 düzeyinde baba bağlanma $\left[X^{2}(3)=14.913, p<.05\right]$ ve uzlaşılabilirlik $\left[X^{2}(3)=10.651, p<.05\right]$ puanları açısından anlamlı bir fark saptanmıştır. Farklı olan grubu bulmak için yapılan Mann-Whitney $U$ testine göre, annesi ilkokul mezunu olan öğrencilerin baba bağlanma puanlarının ortalamasının ( $\bar{x}=61.2057)$, annesi üniversite mezunu $(\bar{x}=48.2353)$, ortaokul mezunu ( $\bar{x}=54.222)$ ve lise mezunu $(\bar{x}=60.52)$ olanlardan daha yüksek olduğu görülmektedir. Uzlaşılabilirlik puanlarındaki farka bakıldığında ise annesi ilkokul mezunu ( $\bar{x}=34.5390)$ olan öğrencilerin, annesi üniversite mezunu ( $\bar{x}=30.8824)$ olan öğrencilere göre uzlaşılabilirlik puanları daha yüksektir.

Tablo-4 Öğrencilerin baba öğrenim düzeylerine Göre Kişilik özellikleri ve Bağlanma puanlarına İlişkin Ortalama ve Kruskall-Wallis Analizi Sonuçları

\begin{tabular}{|c|c|c|c|c|c|c|}
\hline Boyutlar & Baba öğrenim & $\bar{x}$ & $\begin{array}{c}\text { Sıra } \\
\text { Ortalaması }\end{array}$ & $x^{2}$ & $\mathrm{P}^{*}$ & $\begin{array}{l}\text { Fark (Mann- } \\
\text { Whitney U) }\end{array}$ \\
\hline \multirow{4}{*}{$\begin{array}{c}\text { Anne } \\
\text { Bağlanma }\end{array}$} & İlkokul & 63.8642 & 129.93 & \multirow{4}{*}{1.205} & \multirow{4}{*}{.752} & \multirow[t]{4}{*}{ 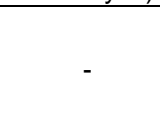 } \\
\hline & Ortaokul & 64.7917 & 132.54 & & & \\
\hline & Lise & 62.8919 & 125.78 & & & \\
\hline & Üniversite & 65.2373 & 139.97 & & & \\
\hline \multirow{4}{*}{$\begin{array}{c}\text { Baba } \\
\text { Bağlanma }\end{array}$} & İlkokul & 59.0370 & 135.21 & \multirow{4}{*}{2.351} & \multirow{4}{*}{.503} & \multirow{4}{*}{-} \\
\hline & Ortaokul & 58.6250 & 128.83 & & & \\
\hline & Lise & 60.2973 & 138.61 & & & \\
\hline & Üniversite & 56.7119 & 119.65 & & & \\
\hline \multirow{4}{*}{$\begin{array}{c}\text { Dışa } \\
\text { dönüklük }\end{array}$} & İlkokul & 26.6296 & 143.35 & \multirow{4}{*}{10.396} & \multirow{4}{*}{$.015^{\star}$} & \multirow{4}{*}{$4>3$} \\
\hline & Ortaokul & 25.1667 & 125.28 & & & \\
\hline & Lise & 24.0541 & 110.47 & & & \\
\hline & Üniversite & 26.8644 & 146.67 & & & \\
\hline \multirow{4}{*}{ Uzlaşılabilirlik } & İlkokul & 34.3210 & 138.30 & \multirow{4}{*}{3.215} & \multirow{4}{*}{.360} & \multirow{4}{*}{-} \\
\hline & Ortaokul & 35.0833 & 142.54 & & & \\
\hline & Lise & 33.1486 & 123.20 & & & \\
\hline & Üniversite & 33.3051 & 123.59 & & & \\
\hline \multirow{4}{*}{ Özdisiplin } & İlkokul & 32.2716 & 134.79 & \multirow{4}{*}{1.194} & \multirow{4}{*}{.754} & \multirow{4}{*}{-} \\
\hline & Ortaokul & 32.2708 & 133.36 & & & \\
\hline & Lise & 32.2838 & 134.21 & & & \\
\hline & Üniversite & 31.6271 & 122.07 & & & \\
\hline \multirow{4}{*}{ Nevrotiklik } & İlkokul & 24.0617 & 118.48 & \multirow{4}{*}{7.699} & \multirow{4}{*}{.053} & \multirow{4}{*}{-} \\
\hline & Ortaokul & 26.8750 & 156.36 & & & \\
\hline & Lise & 24.8919 & 128.66 & & & \\
\hline & Üniversite & 25.2542 & 132.70 & & & \\
\hline \multirow{4}{*}{$\begin{array}{l}\text { Deneyime } \\
\text { açıklık }\end{array}$} & İlkokul & 35.0741 & 126.73 & \multirow{4}{*}{3.135} & \multirow{4}{*}{.371} & \multirow{4}{*}{-} \\
\hline & Ortaokul & 34.9792 & 132.79 & & & \\
\hline & Lise & 34.7297 & 124.38 & & & \\
\hline & Üniversite & 36.2203 & 145.92 & & & \\
\hline
\end{tabular}

Sd (3) $P^{*}<.05 N_{\text {likokul }}=81 N_{\text {Ortaokul }}=48 N_{\text {Lise }}=74 N_{\text {Üniversite }}=59 N_{T}=262$

Tablo 4'de görüldüğü gibi öğrencilerinin baba öğrenim düzeylerine göre Kruskall-Wallis analizi sonucunda .05 düzeyinde dışadönüklük $\left[X^{2}(3)=10.396, p<.05\right]$ puanları açısından anlamlı bir fark saptanmıştır. Farklı olan grubu bulmak için yapılan Mann-Whitney $U$ testine göre, babası üniversite mezunu olan öğrencilerin dışadönüklük puanlarının ortalamasının $(\bar{x}=26.8644)$, babası lise mezunu $(\bar{x}=24.0541)$ ve babası ilkokul mezunu $(\bar{x}=26.6296)$ olan öğrencilerin, babası lise mezunu olanlardan daha yüksek olduğu görülmektedir. 
4- $\quad$ Öğrencilerin ebeveyn bağlanma düzeyleri ve kişilik özellikleri kardeş sayısına göre anlamlı bir farklılık göstermekte midir?

Tablo-5 Öğrencilerin Kardeş Sayılarına Göre Kişilik özellikleri ve Bağlanma puanlarına İlişkin Ortalama ve Kruskall-Wallis Analizi Sonuçları

\begin{tabular}{|c|c|c|c|c|c|c|}
\hline Boyutlar & Anne öğrenim & $\bar{x}$ & $\begin{array}{c}\text { Sıra } \\
\text { Ortalaması }\end{array}$ & $x^{2}$ & $\mathrm{P}^{*}$ & $\begin{array}{l}\text { Fark (Mann- } \\
\text { Whitney U) }\end{array}$ \\
\hline & Tek çocuk & 63.0714 & 123.71 & \multirow{4}{*}{2.125} & \multirow{4}{*}{.547} & \multirow[t]{4}{*}{ 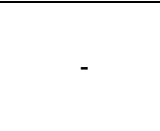 } \\
\hline Anne & İki kardeş & 65.0192 & 137.77 & & & \\
\hline \multirow[t]{2}{*}{ Bağlanma } & Üç kardeş & 62.8804 & 123.21 & & & \\
\hline & Dört ve üstü & 64.5385 & 135.72 & & & \\
\hline & Tek çocuk & 54.6429 & 133.68 & \multirow{4}{*}{1.799} & \multirow{4}{*}{.615} & \multirow{4}{*}{-} \\
\hline Baba & İki kardeş & 57.7981 & 128.75 & & & \\
\hline \multirow[t]{2}{*}{ Bağlanma } & Üç kardeş & 59.1957 & 127.33 & & & \\
\hline & Dört ve üstü & 61.1923 & 143.80 & & & \\
\hline \multirow{4}{*}{ Dışa dönüklük } & Tek çocuk & 26.1429 & 134.14 & \multirow{4}{*}{.952} & \multirow{4}{*}{.813} & \multirow{4}{*}{-} \\
\hline & İki kärdeş & 25.7981 & 132.99 & & & \\
\hline & Üç kardeş & 25.3043 & 125.80 & & & \\
\hline & Dört ve üstü & 26.0192 & 137.90 & & & \\
\hline \multirow{4}{*}{ Uzlaşılabilirlik } & Tek çocuk & 32.1429 & 111.36 & \multirow{4}{*}{9.790} & \multirow{4}{*}{$.020^{*}$} & \multirow{4}{*}{$4>1$} \\
\hline & İki kardeş & 34.8942 & 145.24 & & & \\
\hline & Üç kardeş & 32.9783 & 114.35 & & & \\
\hline & Dört ve üstü & 34.0192 & 139.79 & & & \\
\hline \multirow{4}{*}{ Özdisiplin } & Tek çocuk & 32.7857 & 140.50 & \multirow{4}{*}{1.540} & \multirow{4}{*}{.673} & \multirow{4}{*}{ - } \\
\hline & İki kardeş & 31.5673 & 124.47 & & & \\
\hline & Üç kardeş & 32.5217 & 135.84 & & & \\
\hline & Dört ve üstü & 32.3846 & 135.46 & & & \\
\hline \multirow{4}{*}{ Nevrotiklik } & Tek çocuk & 23.7857 & 124.79 & \multirow{4}{*}{2.370} & \multirow{4}{*}{.499} & \multirow{4}{*}{-} \\
\hline & İki kardeş & 25.7500 & 139.65 & & & \\
\hline & Üç kardeş & 24.5217 & 123.40 & & & \\
\hline & Dört ve üstü & 25.0769 & 131.34 & & & \\
\hline \multirow{4}{*}{$\begin{array}{l}\text { Deneyime } \\
\text { açıklık }\end{array}$} & Tek çocuk & 35.5000 & 138.18 & \multirow{4}{*}{1.870} & \multirow{4}{*}{.600} & \multirow{4}{*}{-} \\
\hline & İki kardeş & 35.6827 & 135.70 & & & \\
\hline & Üç kardeş & 34.3587 & 122.85 & & & \\
\hline & Dört ve üstü & 35.7308 & 136.62 & & & \\
\hline
\end{tabular}

$S d$ (3) $P^{*}<.05 N_{\text {Tek çocuk }}=14, N_{\text {Iki kardeş }}=104, N_{\text {Ụ kardeş }}=92, N_{\text {Dört ve üstü }}=52, N_{T}=262$

Tablo 5'de görüldüğü gibi öğrencilerinin kardeş sayılarına göre Kruskall-Wallis analizi sonucunda .05 düzeyinde uzlaşılabilirlik $\left[X^{2}(3)=9.790, p<.05\right]$ puanları açısından anlamlı bir fark saptanmıştır. Farklı olan grubu bulmak için yapılan Mann-Whitney $U$ testine göre, dört ve üstü kardeş sayısı olan öğrencilerin uzlaşılabilirlik puanlarının ortalamasının ( $\bar{x}=34.0192)$, tek çocuk ( $\bar{x}=32.1429)$ olan öğrencilerden daha yüksek olduğu görülmektedir.

Öğrencilerin doğum sırası, kardeş sayısı ve yaşamının çoğunu geçirdiği yer açılarından da bağlanma ve kişilik özellikleri puanlarının farklılaşıp farkılaşmadığına bakılmış ve anlamlı fark bulunmamıştır.

\subsection{Tartışma}

$\mathrm{Bu}$ çalışmada Marmara bölgesinde bulunan bir üniversitenin 2017- 2018 öğretim yılında Eğitim Fakültesi farklı bölümlerine kayıt yaptıran birinci sınıf öğrencilerinin bağlanma ve kişilik özellikleri arasındaki ilişki incelenmiştir.

Katılımcıların demografik özelliklerine bakıldığında, öğrencilerin ağırıklı olarak orta gelir düzeyindeki ailelerden geldikleri, yüzde 95 'inin en az bir kardeşinin olduğu, annelerinin eğitim düzeyi; yaklaşık yarısının ilkokul, diğer yarısının ise ortaokul-lise, baba eğitim düzeylerine bakıldığında da üçte birinin babasının ilkokul, üçte ikisinin ise ortaokul lise düzeyinde olduğu 
görülmektedir. Demoğrafik verilere genel olarak bakıldığında diğer araştırmalarda da görüldüğü gibi alt ve orta sınıf ailelerden geldikleri söylenebilir.

Araştırmada cevap aranan soruların ilki, öğrencilerin kişilik özellikleri puanları ile ebeveyn bağlanma puanları arasında anlamlı bir ilişki var mıdır? şeklindedir. Çalışmanın sonucunda, katılımcıların anne ve baba bağlanma özellikleri ile dışa dönüklük, yumuşak başlılı ve uzlaşabilirlik özelliği arasında anlamlı ilişki bulunmuştur. Kişilik özelliği açısından dışa dönüklük daha çok kişiler arası ilişkilerde sosyal uyaranların miktarı ile ilişkilidir. Goldberg, (1992) göre, baskınlık ve aktivite dışadönüklük faktörünün temel belirleyicileri arasındadır. Ayrıca sosyallik ve insanlarla birlikte olmayı sevme, eğlenceyi sevme, liderlik, güç, istekli olma ve arkadaşça davranma gibi özellikler de bu faktörü temsil etmektedirler. Basım, Çetin ve Tabak (2009) çalışmasında, dışadönüklük ve özdisiplin kişilik özelliklerinin çatışma çözme süreçlerinde önemli rolü olduğunu buna karşın, nörotiklik özelliğinin çatışma çözme yaklaşımlarını yordamadığını tespit etmişlerdir. Yumuşak başlılık boyutu da kişiler arası ilişkilerde temel bir faktördür. Kişinin kendilik algısını etkilediğine ve sosyal tutumlar geliştirmenin yanı sıra, bir yaşam felsefesi geliştirmekte de etkili olduğuna işaret edilmektedir (Costa, McCrae ve Dye, 1991). Bu faktorde yüksek olan kişiler, başkalarını seven, verici, sosyal ilgisi olan insanlardır. Türk kültürüne özgü bağlanmanın incelendiği bir çalışmada da Halfon (2006) hiyerarşi, düzgün tavır, birliktelik, olumlu bağlanma değişkenlerinin olumlu yönde arttığına ilişkin bulgular elde etmiştir.Güvenli bağlanan kişilerin çoğu ilişkisel alanda daha başarılı görünmektedirler (Dönmez, 2009,77).

Özdisiplin faktörü hem ilerletici hem de ketleyici yönlere sahiptir. Özdisiplin faktörünün başarı intiyacı ve çalışma kararlıığın ilerletici yönü, ketleyici yönü ahlaki titizlilik ve tedbirlilik özelliklerinde ortaya çıkmaktadır.Çocukların sosyal ve duygusal yaşantıları anne babanın onlarla kurduğu ilişkinin niteliği ile ilişkilidir. Aşırı koruyucu anne babaların çocuklarınin özdisiplin konusunda güçlükler yaşayabilecekleri gibi ayrıca bağımlı davranmaya yönelebildiklerine dair sonuçlar da elde edilmiştir. (Ulusoy, Durmuş, 2011).

Nevrotiklik ile baba bağlanma puanları arasında olumsuz yönde düşük anlamlı ilişki saptanmıştır. Birçok araştırmacının nörotisizmin temelinde anksiyete, depresyon, kızgınlık, sıkıntı gibi olumsuz duyguları içerdiği konusuna fikir birliği içinde olduklarına dair sonuçlar bulunmaktadır (Aktaş, 2006; Güleç, 2006; Mete, 2006).

Araştırmada cevap aranan ikinci sorusu; öğrencilerin ebeveyn bağlanma düzeyleri ve kişilik özellikleri cinsiyetlerine göre anlamlı bir farklılık göstermekte midir? şeklindedir. Öğrencilerin cinsiyetlerine göre anne bağlanma düzeylerinde kadınların lehine anlamlı bir fark saptanmıştır. Alanyazında daha küçük yaşlarda kız ergenlerin anneleriyle daha fazla vakit geçirmesinden dolayı, erkek ergenlere oranla anneye bağlanmasının daha fazla olduğuna ilişkin bulgular da bulunmaktadır (Crouter, Manke ve Mchale, 1995; Galambos, Almeida ve Petersen, 1990). Alanyazında üniversite öğrencileri için yapılan kimi araşıırmalarda da kadın üniversite öğrencilerinin anneye bağlanma puanları erkek üniversite öğrencilerinden fazla olduğu bulunmuştur (Bayraktar, Sayıl, ve Kumru, 2009; Matsuoka ve ark., 2006).

Ayrıca, kadınların, erkeklere göre özdisiplin ve nevrotiklik puanlarının daha fazla olduğu saptanmıştır. Tatar (2009) çalışmasında kızların erkeklere göre daha dışadönük, deneyime açık ve nevrotizm düzeylerinin daha yüksek olduğunu belirtmiştir. Tatlılıoğlu'nun (2014), üniversite öğrencileri ile yaptığı araştırmaya göre de benzer biçimde kadın öğrencilerin nevrotiklik özelliğinin erkek öğrencilere gore daha yüksek olduğunu bulmuştur.Schmitt, Realo, Voracek ve Allik'in (2008) kültürlerarası araştırmasında, birçok ülkede kadınların erkeklere oranla daha yüksek düzeyde nevrotiklik, özdisiplin, uyumluluk ve dışa dönüklük özelliği olduğunu bulmuştur. 
Araştırmada cevap aranan bir diğer soru, öğrencilerin ebeveyn bağlanma düzeyleri ve kişilik özellikleri anne/ baba öğrenim düzeylerine göre anlamlı bir farklılık göstermekte midir? şeklindedir. Öğrencilerinin baba bağlanma puanları annelerinin öğrenim düzeylerine göre farklılaştığı bulunmuştur. Annelerin öğrenim düzeyi arttıkça baba bağlanma puanları düşmektedir. Çalışma üniversite öğrencileri ile yapıldığından, ebeveynlerin eğitim düzeyi, çocuklarıyla kurdukları iletişime etki etmesinden kaynaklandığı şeklinde yorumlanabilir. Bu başlıktaki diğer bulgular ise öğrencilerin kişilik özellikleri ve anne baba öğrenimiyle ilgilidir: annesi ilkokul mezunu olan öğrencilerin uzlaşılabilirlik puanları, annesi lise ve üniversite mezunu olanlara nazaran daha yüksek; babası üniversite mezunu olan öğrencilerin, babası lise ve üniversite mezunu olan öğrencilere nazaran dışadönüklük puanlarının daha yüksek olmasıdır.

Literatür incelendiğinde anne-baba öğrenim düzeyi değişkenleri ile kişilik alt boyutları arasında ilişkiyi inceleyen bir çalışmaya rastlanmamıştır. Ancak ailenin sosyo ekonomik düzeyi arttıkça çocukların dışadönüklük özelliklerinin daha arttığına dair sonuçlar bulunmaktadır (Kagıtçıbaşı, 1973).

Uzlaşılabilirlik puanlarındaki farka bakıldığında ise annesi ilkokul mezunu olan öğrencilerin, annesi üniversite mezunu olan öğrencilere göre uzlaşılabilirlik puanları daha yüksektir.Annesi ilkokul mezunu olan bireylerin daha geleneksel anlayışla büyütüldüğü göz önüne alındığında özellikle kız çocuklarının daha uyumlu, yumuşak başlı, merhametli olmaları yönünde yetiştirildikleri söylenebilir. Dolayısıyla annesi ilkokul mezunu olanların uzlaşabilirlik puanlarının yüksek olması bu bakış açısıyla açıklanabileceği düşünülmektedir.Çocuk bakımı hakkında bilgi düzeyi arttıkça eğitim alma faktörü annelerin çocukları ile doğal ilişkilerinin yerini kaygılı anne davranışlarına bırakması bağlanma üzerine etki edebilicek bir durumdur. Geleneksel Türk kültüründe annelik, eğitim düzeyine bakılmaksızın erken yaşlardan itibaren bir kadının iyi bir şekilde gerçekleştirmesi gereken bir rol olarak görülür(Kesicioğlu, 2015).

Araştırmanın son sorusunda ise öğrencilerin ebeveyn bağlanma düzeyleri ve kişilk özellikleri kardeş sayısına göre anlamlı bir farklılık gösterip göstermediğine bakılmıştır. Uzlaşılabilirlik kişilk özelliğinin kardeş sayısına göre farklılaştığı bulunmuştur. Buna göre, kardeş sayısı arttıkça uzlaşılabilirlik özelliğinin de arttığı bulunmuştur. Kardeş sayısı dört üstü olanların uzlaşabilirlik puanlarının daha yüksek olması Türk kültüründe kardeş sayısının artması çocukların aile içinde paylaşımcılığını arttıran bir durum olarak düşünülebilir.

Kerri Ritchie'nin (2003), çalışmasında, üniversiteye uyumda anne babaya bağlılık ve akran desteğinin uyum sağlamada önemli bir faktör olarak saptamıştır. 


\subsection{Sonuç ve Öneriler}

Anne/babaya güvenli bağlanma düzeylerinde cinsiyetin, anne öğreniminin ve kardeş sayısının etkili olduğu görülmüştür.Bu bağlamda üniversiteye yeni başlayan öğrencilerin kişisel gelişimlerine katkı sağlayacak eğitim programlarının kardeş sayısı fazla olan, anne baba öğrenim düzeyleri daha düşük olan öğrencilerin daha fazla intiyaç duyabilecekleri düşünülebilir. Anne/babaya güvenli bağlanma düzeyi dışadönüklük, uzlaşabilirlik ve öz disiplin ile olumlu yönde anlamlı ilişki göstermiştir. Bağlanma düzeyi düşük olan öğrencilerde dışadönüklük, özdisiplin ve uzlaşabilirlik konularında destek programları geliştirilebilir. Bu bağlamda baba bağlanmasının düşük olduğu kişilere yönelik olarak benlik saygısı ve uygun başetme yöntemlerinin kazandırılması konusunda çalışmalar yapılabileceği düşünülmektedir.

Bu çalışma eğitim fakültesi öğrencileri ile sınırlıdır. Tüm üniversiteyi kapsayan, farklı fakültelerde öğrenim gören öğrencilerle yapılacak bir çalışma ile, öğrencilerin bu farklııktan etkilenip etkilenmediği incelenebilir.. 


\section{KAYNAKLAR}

Ainsworth, M. D. S. (1989). Attachment beyond infancy. American Psychologist, 44: 709-716.

Aktaş, A. (2006). Farklı kültürlerdeki yöneticilerin kişilik özelliklerine dayanarak liderlik anlayışlarının belirlenmesi: Türk ve Amerikan otel yöneticilerinin karşılaştırmalı analizi. (Yayınlanmamış Yüksek Lisans Tezi). Akdeniz Üniversitesi Sosyal Bilimler Enstitüsü, Antalya

Akhunlar, M. N. (2010). An investigation about the relationship between life satisfaction and loneliness of nursing students in Uşak University. Procedia - Social and Behavioral Sciences, 5(2), 2409-2415. https://doi.org/10.1016/j.sbspro.2010.07.472

Allen, J. P., Hauser, S.T., Eickholt, C., Bell, K. L. ve O'Connor, T. G. (1994). Autonomy and relatedness in family interactions as predictors of expressions of negative adolescent affect. Journal of Research on Adolescence, 4(4), 535-552.

Aslan, S. ve Güven, M. (2010). Bağlanma ve kişisel uyum arasındaki ilişkide ayrışma bireyleşmenin aracılığı. Eğitim ve Bilim, 35(157).

15.11.2017, http://egitimvebilim.ted.org.tr/index.php/EB/article/view/396/164 adresinden erişildi.

Bacanlı, H, İlhan, T. ve Aslan, S. (2009). Beş faktör kuramına dayalı bir kişilik Ölçeğinin geliştirilmesi: sıfatlara dayalı kişilik testi (sdkt), Türk Eğitim Bilimleri Dergisi, 7(2), 261- 279.

Bartholomew, K. ve Horowitz L. M. (1991). Attachment styles among young adults: A test of a four-category model. Journal of Personality and Social Psychology, 61,226-244

Bayraktar, F., Sayıl, M., Kumru, A. (2009). Liseli ergenler ve üniversiteli gençlerde benlik saygisi: Ebeveyn ve akrana baglanma, empati ve psikolojik uyum degiskenlerinin Rolü/Selfesteem among high-school adolescents and college students: The role of parental and peer attachment, empathy and psychological adjustment variables. Türk Psikoloji Dergisi, 24(63), 48-68.https://search.proquest.com/docview/816748490?accountid=16382

Benet-Martínez, V., \& John, O. P. (1998). Los Cinco Grandes across cultures and ethnic groups: multitrait multimethod analyses of the Big Five in Spanish and English. Journal of Personality and Social Psychology, 75(3), 729-750. https://doi.org/10.1037/0022$\underline{3514.75 .3 .729}$

http://citeseerx.ist.psu.edu/viewdoc/download?doi=10.1.1.526.5908\&rep=rep1\&type=pdf

Bowlby J. (1958). The nature of the child's tie to his mother. International Journal of PsychoAnalysis. 39:350-373.

Bowlby, J. (1979). The making and breaking of affectional bonds. Londra: Tavistock.

Bowlby, J. (1988). A Secure Base: clinical applications of Attachment Theory. London, Routledge 
Carver, C. (1997). Adult attachment and personality: Converging evidence and a new measure. Personality and Social Psychology Bulletin. 23(8):865-883.

http://www.psy.miami.edu/faculty/ccarver/documents/p97_attachmt.pdf

Creswell, J.W. (2005). Educational research: Planning, conducting and evaluating quantitative and qualitative research (2nd ed.), Upper Saddle River, N.J.: Pearson Merrill Prentice Hall

Crouter, A. C, Manke, B. A. ve McHale, S. M. (1995). The family context of gender intensifi cation in early adolescence. Child Development, 66, 317-329.

Çalışır, M. (2009). Yetişkin Bağlanma Kuramı ve Duygulanım Düzenleme Stratejilerinin Depresyonla İlişkisi. Psikiyatride Güncel Yaklaşımlar, 1(3), 240-255. http://dergipark.ulakbim.gov.tr/pskguncel/article/view/5000076416

Damian, R. I., \& Roberts, B. W. (2015). The associations of birth order with personality and intelligence in a representative sample of U.S. high school students. Journal of Research in Personality, 58, 96-105. https://doi.org/10.1016/j.jrp.2015.05.005

David P. Schmitt, Jüri Allik, Robert R. McCrae, Verónica Benet-Martínez (2007), The Geographic Distribution of Big Five Personality TraitsPatterns and Profiles of Human SelfDescription Across 56 Nations, Journal of Cross-Cultural PsychologyVolume: 38 issue: 2, page(s): 173-212Issue published: March 1, 2007 https://doi.org/10.1177/0022022106297299

Dönmez, A. (2009). Yakın İlişsiler Psikolojisi (Çev. Edt. Ali Dönmez). Nobel Yayıncılık, Ankara.

Erözkan, A. (2011). Üniversite öğrencilerinin bağlanma stilleri ve karar stratejileri. International journal of eurasia social sciences. http://dergipark.ulakbim.gov.tr/ijoess/article/view/5000039509

Fraenkel, J. R. \& Wallen, N. E. (2003). How to design and evaluate research in education (5th ed.). Boston: McGraw-Hill.

Fraley, R.C. ve Shaver, P. R. (2000). Adult romantic attachment: theorical developments emerging controversies, and unanswered questions. Review of General Psychology 4(2): 132-154.

Galambos, N. L., Almeida, D. M. ve Petersen, A. C. (1990). Masculinity, femininity, and sex role attitudes in early adolescence: Exploring gender intensifi cation. Child Development, 61, 1905-1914.

Güleç, Cengiz (2006). Psikiyatrinin A-B-C'si. İstanbul: Say Yayınları. 
Günaydın, G., Selçuk, E., Sümer, N., \& Uysal, A. (2005). Ebeveyn ve Arkadaşlara Bağlanma EnvanteriKısa Formu'nun Psikometrik AçıdanDeğerlendirilmesi. Türk Psikoloji Yazıları, 8(16), 13-23.

Goldberg, L. R. (1992). The Development of Markers for the Big-Five Factor Structure. Psychological Assessment, 4(1), 26-42. https://doi.org/10.1037/1040-3590.4.1.26

Halfon, S. (2006). Attachment in a Cultural Framework. (The Degree of Master), Boğaziçi University Social Sciences, İstanbul

Permanent URL of this record is: http://seyhan.library.boun.edu.tr/record=b1422763 S5

Hazan, C. ve Shaver, P. (1987) Romantic love conceptualized as an attachment process. Journal of Personality and Social Psychology, 52: 511-524.

Hazan, C. ve Zeifman, D. (1994). Sex and the psychological tether. In K. Bartholomew and D. Perlman (Eds.), Advances in personal relationships, 5. 151-178.

Kagitcibasi, C. (1973). Psychological Aspects of Modernization in Turkey. Journal of CrossCultural Psychology, 4(2), 157-174. https://doi.org/10.1177/002202217300400202

Kalkan, M. Ve Odacı, H. (2010). Psikolojik doğum sırası ve anne babaya bağlanma: Okul öncesi öğretmen adayları üzerine bir çalışma. NWSA: Education Sciences, 5(3), 810-819.

Kaptan, S. (1998). Bilimsel araştırma ve istatistik teknikleri. Ankara: Tekışık Web Ofset Tesisleri

Karasar, N. (2005), Bilimsel araştırma yöntemi, 15. Basım, Nobel Yayın Dağıtım, Ankara

Kesicioğlu, O. S. (2015). Investigation Of Preschool Children's Interpersonal Problem Solving Skills. Egitim ve Bilim / Education and Science, 40(177), 327-342.

https://doi.org/10.15390/EB.2015.3240

Liberman,R.R (2011). Yetiyitiminden iyileşme. Psikiyatrik iyileştirim el kitabı. American Psychiatric Publishing, Inc England

Matsuoka N, Uji M, Hiramura H, Chen Z, Shikai N, Kishida Y ve Kitamura, T. (2006). Adolescents attachment style and early experiences: A gender difference. Arch Womens Ment Health, 9. 23-29.

Mccrae, R.R., Costa, P.T. (1989). Reinterpreting the Myers-Briggs type indicator from the perspective of the five-factor model of personality. Journal of Personality, 57, 17-40.

Mccrae, R.R., Costa, P.T. (1992). Four ways five factors are basics. Personality and Individual Differences , 13(6), 653-665. 
Mccrae, R.R., Costa, P.T. (2003). Personality in adulthood: A five factor theory perpective (2nd ed.) New York: Guilford Press.

Melillo, D. ve College, B. (1983). Birth order, perceived birth order and family position of academic women. The Journal of Adlerian Theory Research and Practice. 39: 57-62.

Mete, Cengiz (2006). İlköğretim okullarında çalışan öğretmenlerin kişilik özellikleri ile iş tatminleri arasındaki ilişkinin incelenmesi. (Yayımlanmamış Yüksek Lisans Tezi), Yeditepe Üniversitesi, Sosyal Bilimler Enstitüsü, İstanbul.

Mikulincer, M., ve Shaver, P. R. (2007b). Boosting attachment security to promote mental health, prosocial values, and inter-group tolerance. Psychological Inquiry, 18, 139156.

http://eds.b.ebscohost.com/eds/pdfviewer/pdfviewer?vid=1\&sid=25705c2e-a3b2-46ee-a589f17798f9b80a\%40pdc-v-sessmgr01

Ritchie, K. (2003). Factors Affecting the Transition to University, (Yayınlanmamış Doktora Tezi). The University of New Brunswick, New Brunswick

Salmon, C. (2002). Birth order and relationships. Human Nature, 14(1): 73-88.

Schmitt, D. P., Realo, A., Voracek, M., ve Allik, J. (2008). Why Can't A Man Be More Like A Woman? Sex Differences in Big Five Personality Traits Across 55 Cultures. Journal of Personality and Social Psychology, 94: 168-182

Shaver, P. R. ve Brennan, K. A. (1992). Attachment Styles and the "Big Five" Personality Traits: Their Connections with Each Other and with Romantic Relationship Outcomes. Society for Personality and Social Psychology, 18(5): 536-545.

Somer, O., Korkmaz, M., Tatar, A. (2002). Beş faktör kişilik envanterinin geliştirilmesi-I: Ölçek ve alt ölçeklerinin oluşturulması. Türk Psikoloji Dergisi, 17(49), 21-33

Steinberg, L. (2005). Adolescence. Stephen B. Rutter. Seventh Edition.

Wilkinson, R. B. ve Walford, W. A. (2001). Attachment and personality in the psychological health of adolescents. Personality and Individual Differences, 31, 473-484. 